\title{
Diplopia Due to Orbital Myositis: Diagnosis with Magnetic Resonance Imaging
}

\author{
Orbital Myozite Bağlı Çift Görme: Manyetik Rezonans Görüntüleme ile Birlikte Tanısı
}

\author{
(D) Aslı Tanrıvermiş Sayıt'1 , (1) Muzaffer Elmalı1', (1) Innci Güngör²
}

10ndokuz Mayıs University Faculty of Medicine, Department of Radiology, Samsun, Turkey

${ }^{2}$ Ondokuz Mayıs University Faculty of Medicine, Department of Ophthalmology, Samsun, Turkey

\begin{abstract}
Orbital myositis is a non-specific inflammatory disease primarily affecting the extraocular muscles. It is most commonly seen in young adults and women and is often unilateral. Periorbital pain, swelling and redness of the eyelid, limitation of eye movements, and diplopia can be seen in patients with this condition. It may be idiopathic or may develop due to secondary diseases such as systemic or infectious causes. Radiological imaging methods such as computed tomography and magnetic resonance imaging are very useful in its differential diagnosis. The response to oral corticosteroid treatment is very good. In this study, we report the clinical and radiological features of a 13-year-old girl diagnosed with orbital myositis, who experienced a complete recovery with steroid treatment.
\end{abstract}

Keywords: Lateral rectus muscle, magnetic resonance imaging, myositis, steroid

\section{öz}

Orbital miyozit, özellikle ekstraoküler kasları etkileyen, spesifik olmayan enflamatuvar bir hastalıktır. Genellikle genç erişkinlerde ve kadınlarda görülür ve çoğunlukla tek taraflıdır. Hastalarda periorbital ağrı, göz kapağının șișmesi ve kızarıklığı, göz hareketlerinde kısıtılık ve diplopi görülebilir. İdiyopatik olabilir veya sistemik veya enfeksiyöz nedenler gibi sekonder hastalıklara bağlı meydana gelebilir. Bilgisayarlı tomografi ve manyetik rezonans görüntüleme gibi radyolojik görüntüleme yöntemleri ayırıcı tanıda çok yararlıdır. Oral kortikosteroid tedavisine verilen cevap çok iyidir. Biz burada steroid ile tedavi edilen orbital miyozit tanılı 13 yaşında kız çocuğunun klinik ve radyolojik özelliklerini ilgili literature eşliğinde sunmayı amaçladık.

Anahtar Kelimeler: Lateral rektus kası, manyetik rezonans görüntüleme, miyozit, steroid
Address for Correspondence/Yazıșma Adresi: Aslı Tanrıvermiş Sayıt MD, Ondokuz Mayıs University Faculty of Medicine, Department of Radiology, Samsun, Turkey

Phone: +90 5324949082 E-mail: draslitanrivermissayit@gmail.com ORCID ID: orcid.org/0000-0003-2861-156X

Cite this article as/Atıf: Tanrıvermiş Sayıt A, Elmalı M, Güngör I. Diplopia Due to Orbital Myositis: Diagnosis with Magnetic Resonance Imaging. İstanbul Med J 2019; 20(3): 264-6. is usually unilateral and response to steroid treatment is very good (1). In this article, we report on the case of a 13-year-old girl who was diagnosed with idiopathic orbital myositis through MRI findings after being admitted to the hospital with double vision.

\section{Case Report}

A 13-year-old girl was admitted to the hospital with acute onset of diplopia on gazing to the right, with an accompanying headache. She had no previous trauma or symptoms suggesting increased intracranial pathology. She had recently been diagnosed with a viral upper respiratory tract infection. Upon the physical examination, her visual acuity was revealed to be normal in both eyes. In addition, bilateral anterior segment, intraocular pressure, and fundus were normal. The eyes were orthophoric in the primary position, but there was a -1 degree 
restriction to the lateral side in the right eye. Complete blood count, thyroid hormones, and antithyroid antibodies were within normal limits. A contrast enhanced orbital and brain MRI was performed for the differential diagnosis of diplopia. The brain MRI was normal. Also, high signal intensity and thickening in the right lateral rectus muscle and tendon were seen on the T2-WI of orbital MRI (Figure 1). An intensive contrast enhancement was observed in the right lateral rectus muscle and tendon on contrast enhanced T1-WIs (Figure 2a, b).

Based on the clinical, laboratory, and MRI findings, the patient was diagnosed with orbital myositis. We initiated the treatment with oral $64 \mathrm{mg} / \mathrm{kg}$ prednisolone per day and continued for one week. Then, the dosage of the drug was gradually reduced. Her pain and gaze paresis disappeared completely after treatment. High T2 signal intensity,

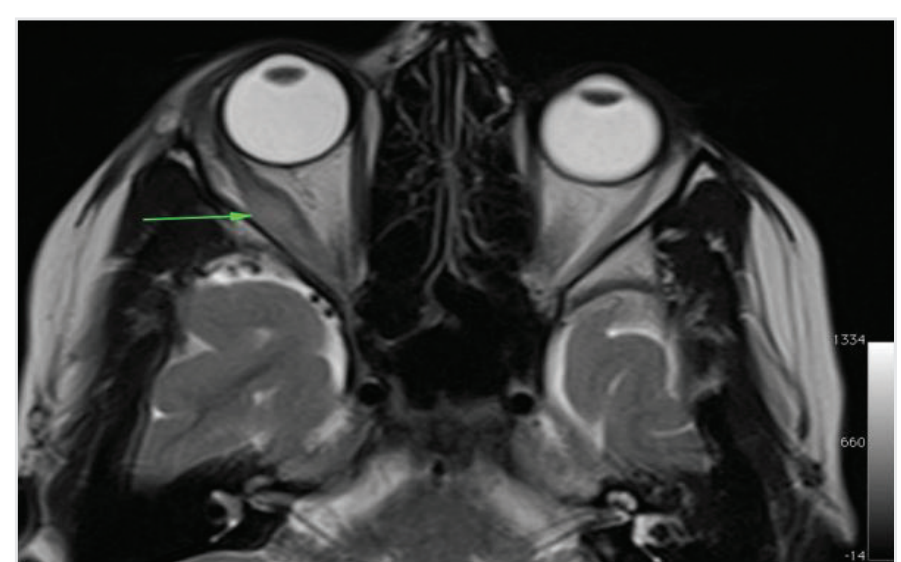

Figure 1. Axial T2-weighted image shows thickening and high signal intensity in the right lateral rectus muscle (arrow)
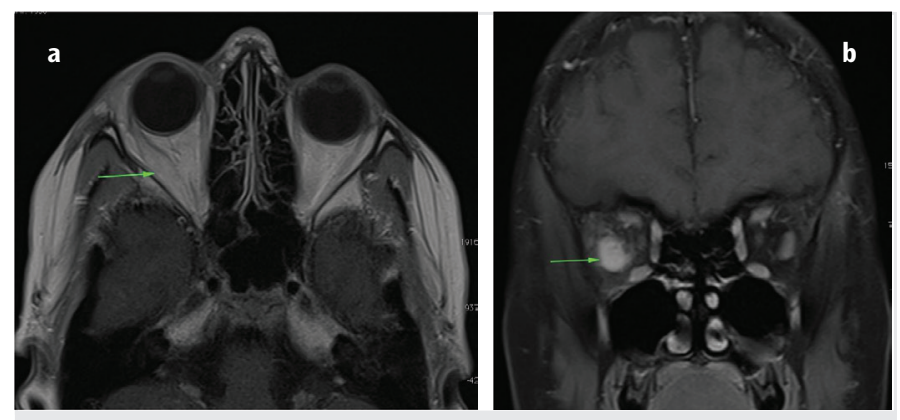

Figures $2 \mathbf{a}$, b. Contrast-enhanced axial a) and coronal fat-suppressed b) T1-weighted images show mild-to-significant contrast enhancement of the enlarged right lateral rectus muscle (arrow)
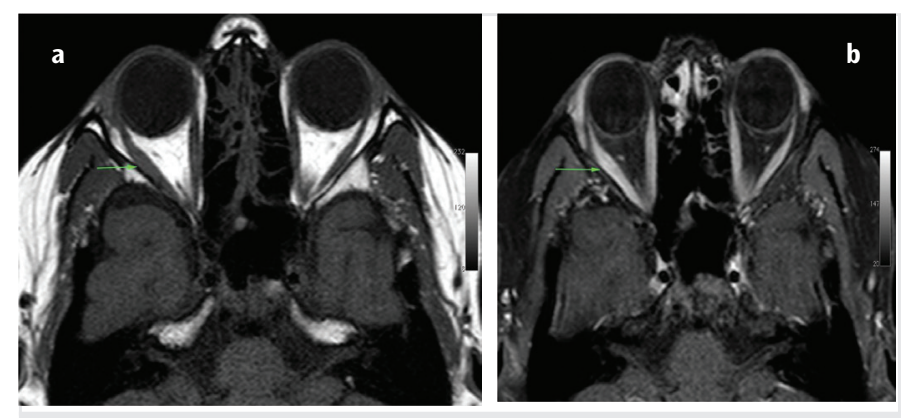

Figures 3a, b. Axial T2-weighted image (WI) a) shows no abnormal signa intensity in the right lateral rectus muscle. b) Also, there was no abnormal contrast enhancement in the right lateral rectus muscle on contrastenhanced axial fat-suppressed T1-WI thickening, and pathologic contrast enhancement in the right lateral rectus muscle and tendon disappeared from the orbital MRI after the treatment (Figures 3a, b). There was no recurrence after six months.

Verbal informed consent was obtained from the patient who participated in this case study.

\section{Discussion}

The most common diseases of the orbits are thyroid orbitopathy, lymphoproliferative diseases, and orbital myositis (2). Orbital myositis is an inflammatory disease of the extraocular muscles that is most commonly seen in young and middle-aged people. The characteristic clinical triad include periorbital pain, diplopia, and signs of inflammation, such as conjunctival injections or swelling. Concurrent pain is present in $>95 \%$ of all cases (1). The most common presentation is that of unilateral single muscle involvement though multiple or bilateral involvement can also be seen (4). Superior, lateral, and medial rectus muscles are equally involved frequently, and recurrence occurs in $56 \%$ of cases $(5,6)$.

Although the etiology of the condition is not completely known, infectious and autoimmune-related factors are thought to play a role. Cases of autoimmune-related orbital myositis are associated with diseases including giant cell myocarditis, Crohn disease, systemic lupus erythematosus, rheumatoid arthritis, and linear scleroderma. Also, spirochetotic (Lyme disease) (7), viral (herpes zoster virus) (8), and bacterial infections (group A streptococcal pharyngitis) (9) can cause orbital myositis.

A diagnosis of orbital myositis is usually made via physical examination. Laboratory tests, such as complete blood count, hepatic and renal function tests, erythrocyte sedimentation rate, c-reactive protein levels, thyroid function tests, and various antibodies, can also be performed (2). The differential diagnosis of orbital myositis includes the following: infections (viral infections, orbital cellulitis, orbital abscess), inflammatory reaction (trauma, foreign body, bisphosphonaterelated reaction, and postvaccinal reaction), Tolosa-Hunt syndrome, thyroid ophthalmopathy, vasculitis, systemic lupus erythematosus, sarcoidosis, inflammatory bowel disease, neoplasm, arteriovenous fistulas, and malformations (2). Orbital myositis should be distinguished primarily from thyroid orbitopathy. Thyroid function tests and thyroid ultrasonography can be performed for the differential diagnosis. Moreover, imaging methods such as computed tomography (CT) and MRI are also very useful. Thyroid orbitopathies are usually bilateral (85\%) and rarely unilateral (10-30\%) (10). CT and MRI reveal enlarged muscle bellies and thickened tendons in orbital myositis. By contrast, thyroid orbitopathy only involves the extraocular muscles and not their tendons (4). Furthermore, normal thyroid function tests and negative antithyroid antibodies exclude thyroid orbitopathy.

Spontaneous remission may occur without treatment in orbital myositis. Also, the response to systemic steroid treatment is very good (1). Steroid therapy reduces the risk of muscle fibrosis and recurrence, however, relapse or recurrent inflammation may occur despite the treatment with steroids (11). Multiple muscle involvement, male gender, eyelid retraction, and lack of response to systemic corticosteroids are 
associated with recurrent orbital myositis (12). Low-dose external beam radiation therapy or immunosuppressive agents may be used in cases with multiple recurrences and steroid-resistance (4). Our case responded well to steroid treatment and the lateral rectus muscle was completely normal in the control MRI performed after two months.

\section{Conclusion}

Orbital myositis is an inflammatory disease of the extraocular muscles that is most commonly seen in young and middle-aged people. Orbital myositis should be differentiated from infections, inflammatory reactions, Tolosa-Hunt syndrome, thyroid orbitopathies, vasculitis, and neoplasms. The response to systemic steroid treatment is very good. In addition, steroid therapy reduces the risk of muscle fibrosis and recurrence.

Informed Consent: Verbal informed consent was obtained from the patient who participated in this case study.

Peer-review: Externally peer-reviewed.

Author Contributions: Concept - A.T.S., M.E., I.G.; Design - A.T.S., M.E., I.G.; Supervision - A.T.S., M.E., I.G.; Resources - A.T.S., I.G.; Materials A.T.S., M.E.; Data Collection and/or Processing - A.T.S., I.G.; Analysis and/ or Interpretation - A.T.S., I.G.; Literature Search - A.T.S.; Writing Manuscript - A.T.S., I.G.; Critical Review - A.T.S., M.E., I.G.

Conflict of Interest: No conflict of interest was declared by the authors.

Financial Disclosure: The authors declared that this study received no financial support.

\section{References}

1. Fischer M, Kempkes U, Haage P, Isenmann S. Recurrent orbital myositis mimicking sixth nerve palsy: diagnosis with MR imaging. AJNR Am J Neuroradiol 2010; 31: 275-6.

2. Önder O, Bilgin RR, Köșkderelioğlu A, Gedizlioğlu M. Orbital myositis: evaluating five new cases regarding clinical and radiological features. Noro Psikiyatr Ars 2016; 53: 173-7.

3. Yan J, Wu P. Idiopathic orbital myositis. J Craniofac Surg 2014; 25: 884-7.

4. Court JH, Janicek D. Acute unilateral isolated ptosis. BMJ Case Rep 2015: 2015.

5. Dubey A, Eidsness R, Koul R. Idiopathic orbital myositis and review of literature. The Internet Journal of Ophthalmology and Visual Science 2009; 8: $1-5$.

6. Mombaerts I, Koornneef L. Current status in the treatment of orbital myositis. Ophthalmology 1997; 104: 402-8.

7. Seidenberg KB, Leib ML. Orbital myositis with Lyme disease. Am J Ophthalmol 1990; 109: 13-6

8. Kawasaki A, Borruat FX. An unusual presentation of Herpes zoster ophthalmicus: orbital myositis preceding vesicular eruption. Am J Ophthalmol 2003; 136: 574-5.

9. Alshaikh M, Kakakios AM, Kemp AS. Orbital myositis following streptococcal pharyngitis. J Paediatr Child Health 2008; 44: 233-4.

10. Chakor RT, Santhosh NS. Painless orbital myositis. Ann Indian Acad Neurol 2012; 15: 224-6

11. Jacobs D, Galetta S. Diagnosis and management of orbital pseudotumour. Curr Opin Ophthalmol 2002; 13: 347-51.

12. Mannor G, Rose GE, Moseley IF, Wright JE. Outcome of orbital myositis: clinical features associated with recurrence. Ophthalmology 1997; 104: 409-14. 